\title{
PENGARUH KONSELING KONTRASEPSI HORMONAL TERHADAP TINGKAT PENGETAHUAN AKSEPTOR KELUARGA BERENCANA PASCA PERSALINAN DI WILAYAH KERJA BIDAN PRAKTIK MANDIRI LISMARINI PALEMBANG
}

\author{
Siti Amallia ${ }^{1}$, Rahmalia Afriyani ${ }^{2}$, Yuni Permata Sari ${ }^{3}$ \\ ${ }^{1,2,3}$ STIK Siti Khadijah Palembang \\ Email: azesilia.89@gmail.com
}

\begin{abstract}
The Effect of Hormonal Contraception on Level Knowledge of Family Planning Acceptors Knowledge after Postpartum in the BPM Lismarini Palembang. The lack of family planning acceptors postpartum influenced by the mother's knowledge about family planning. The Aimed of the im study is to know the effect of hormonal contraception counseling on level knowledge of family planning acceptors knowledge after postpartum in the BPM Lismarini Palembang. This study uses Pre experiments with form design study is a one-group pretest-posttest design using minimal sample Sampling with 17 respondents taken by purposive sampling technique. The result showed the average value of knowledge of family planning acceptors postpartum counseling before being given the length is 6.12 while the average value of knowledge of postpartum family planning acceptors after being given counseling is 10.50 with an average difference value 4,471 . Statistical test results using a $\mathrm{T}$-dependent test values obtained $\mathrm{p}$ value $=$ 0.000 means that the value of $\mathrm{p}<\alpha(0,05)$, meaning that there is a hormonal contraceptive counseling influence on the level of knowledge of family planning acceptors postpartum.
\end{abstract}

Keywords : Counseling, Level of knowledge, Contraception

\begin{abstract}
Abstrak: Pengaruh Konseling Kontrasepsi Hormonal terhadap Tingkat Pengetahuan Akseptor Keluarga Berencana Pasca Persalinan di Wilayah Kerja Bidan Praktik Mandiri Lismarini Palembang. Masalah kurangnya akseptor keluarga berencana pasca persalinan dipengaruhi oleh pengetahuan ibu tentang keluarga berencana. Tujuan penelitian ini adalah diketahuinya pengaruh konseling kontrasepsi hormonal terhadap tingkat pengetahuan akseptor keluarga berencana pasca persalinan di wilayah kerja bidan praktik mandiri lismarini palembang. Penelitian ini menggunakan metode Pre eksperiment dengan bentuk desain penelitian yang digunakan adalah one-group pretest-postest design Pengambilan sampel menggunakan sampel minimal dengan jumlah 17 responden diambil dengan tehnik purposive sampling. Hasil penelitian didapatkan nilai rata-rata pengetahuan akseptor keluarga berencana pasca persalinan sebelum diberikan konseling lamanya adalah 6,12 sedangkan nilai rata-rata rata pengetahuan akseptor keluarga berencana pasca persalinan setelah diberikan konseling adalah 10,50 dengan perbedaan nilai rata-rata 4,471. Hasil uji statistik dengan menggunakan uji T-dependen didapatkan nilai $\mathrm{p}$ value $=0.000$ berarti nilai $\mathrm{p}<\alpha(0.05)$, artinya ada pengaruh konseling kontrasepsi hormonal terhadap tingkat pengetahuan akseptor keluarga berencana pasca persalinan.
\end{abstract}

Kata kunci: Konseling, Tingkat pengetahuan, Kontrasepsi

Berdasarkan Laju Pertumbuhan Penduduk (LPP) jumlah kelahiran di indonesia mengalami peningkatan setiap tahunnya, oleh karena itu pemerintah membuat suatu program keluarga berencana. keluarga berencana merupakan salah satu program untuk menurunkan angka kematian penduduk melalui pencegahan kehamilan, penundaan usia kehamilan serta menjarangkan kehamilan dengan sasaran utama adalah pasangan usia subur (BKKBN, 2011).

Menurut World Population Data Sheet 2013, Indonesia merupakan negara ke-5 di dunia dengan estimasi jumlah penduduk terbanyak, yaitu 249 juta, diantara negara ASEAN, Indonesia dengan luas wilayah terbesar tetap menjadi negara dengan penduduk terbanyak, jauh di atas 9 negara anggota lain, dengan Angka fertilitas atau Total Fertility Rate (TFR) 2,6 juta. Indonesia masih berada jauh di atas rata-rata TFR negara ASEAN yaitu 2,4 juta.

Data Badan Kependudukan dan Keluarga Berencana Nasional (BKKBN) menunjukan bahwa pada tahun 2013, ada 8.500.247 PUS (Pasangan Usia Subur) yang merupakan peserta KB Baru, dan hampir separuh nya $(48,56 \%)$ menggunakan metode kontrasepsi suntikan. 
dilihat dari jenis kelamin, metode kontrasepsi perempuan yang digunakan jauh lebih besar di banding dengan metode kontrasepsi laki-laki. Metode kontrasepsi perempuan sebesar 93,66\%, sementara metode kontrasepsi laki-laki hanya sebesar $6,34 \%$. ini menunjukkan bahwa partisipasi laki-laki menggunakan kontrasepsi masih sangat kecil. penggunanaan alat kontrasepsi masih dominan dilakukan oleh perempuan.

Data Riskesdas tahun 2013, menunjukan bahwa pada wanita usia 15-49 tahun ada 1000 orang, dengan status kawin terbesar 59,3\% menggunakan metode KB modern (Implan, MOW, IUD, Kondom, suntikan, pil), 0,4\% menggunakan metode $\mathrm{KB}$ tradisional (menyusui/MAL, pantang berkala/kalender, senggama terputus, lainnya), $24,7 \%$ pernah melakukan $\mathrm{KB}$, dan $15,5 \%$ tidak pernah melakukan KB.

Keluarga Berencana pasca persalinan adalah pelayanan KB yang di berikan kepada pasien pasca persalinan sampai kurun waktu 42 hari setelah persalinan. pada laporan bulan Februari tahun 2015 mencatat bahwa hasil pelayanan peserta KB Baru Pasca Persalinan yaitu sebanyak 94.311 peserta, Metode yang paling banyak di gunakan oleh peserta KB Baru Pasca Persalinan yaitu metode suntikan sebanyak 53.613 peserta $(56,85 \%)$ sedangkan untuk peserta KB baru Pasca Persalinan yang menggunakan Metode Kontrasepsi Jangka Panjang (MKJP) yaitu sebanyak 22.337 peserta $(23,68 \%)$. Selain itu peserta KB baru pasca persalinan yang menggunakan metode $\mathrm{KB}$ pria hanya sebanyak 2.276 peserta $(2,41 \%)$ (BKKBN, 2015).

Berdasarkan data BKKBN Sumsel tahun 2012, jumlah seluruh peserta KB baru berjumlah 463.957 orang $(45,90 \%)$, jumlah peserta KB baru Metode Kontrasepsi Jangka Panjang (MKJP) berjumlah 54.962 orang $(45,49 \%)$, peserta KB baru IUD 9.180 orang $(49,83 \%)$, peserta KB baru Metode Operasi Wanita (MOW) berjumlah 1.897 orang $(50,29 \%)$, peserta KB baru IMPLAN berjumlah 43.030 orang $(44,04 \%)$, peserta KB baru Suntikan berjumlah 207.060 orang $(47,58 \%)$, peserta KB baru PIL berjumlah 160.375 orang $(45,33 \%)$, peserta KB baru Metode Operasi Wanita (MOW) berjumlah 855 orang $(61,17 \%)$, peserta KB baru Kondom berjumlah 41.560 orang $(40,21 \%)$.

Menurut Data Dinas Kesehatan Kota Palembang tahun 2012, jumlah akseptor KB Metode Kontrasepsi Jangka Panjang (MKJP) berjumlah 320 orang $(6,73 \%)$, dimana yang menggunakan IUD berjumlah 156 orang $(3,28 \%)$, Metode Operasi Pria (MOP) berjumlah 6 orang
$(0,13 \%)$, Metode Operasi Wanita (MOW) berjumlah 12 orang $(0,25 \%)$, IMPLAN berjumlah 146 orang $(3,07 \%)$, sedangkan NON MKJP berjumlah 4.436 orang $(93,27 \%)$, dimana yang menggunakan KB Suntik berjumlah 2.173 orang (45,69\%), PIL berjumlah 2.203 orang $(46,32 \%)$, Kondom 60 orang $(1,26 \%)$.

Berdasarkan data yang diperoleh di BPM Lismarini Palembang, pada tahun 2013 jumlah peserta KB 735 peserta, di antara nya KB suntik $300(40,81 \%)$ peserta, pil $155(21,08 \%)$ peserta, implan $60(8,163 \%)$ peserta, IUD $55(7,48 \%)$ peserta, dan kondom $165(22,44 \%)$ peserta, Pada tahun 2014, jumlah peserta KB 1,290 peserta, diantaranya KB suntik $552(42,80 \%)$ peserta, KB pil $391(30,31 \%)$ peserta, implan $163(12,63 \%)$ peserta, IUD $84(6,51 \%)$ peserta, dan kondom $100(7,75 \%)$ peserta. Dan pada tahun 2015 jumlah peserta KB 1,428 peserta, diantara nya KB suntik $680(47,61 \%)$ peserta, KB pil 410 $(28,71 \%)$ peserta, Implan $171(11,97 \%)$ peserta, IUD 90 (6,30\%) peserta, dan kondom 77 (5,39\%) peserta (BPM Lismarini, 2015).

Salah satu upaya untuk meningkatkan pengetahuan akseptor KB melalui konseling KB. konseling $\mathrm{KB}$ adalah percakapan yang bertujuan untuk membantu calon peserta KB agar memahami norma keluarga kecil bahagia sejahtera (NKKBS). Dengan memberikan konseling tentang $\mathrm{KB}$, pengetahuan ibu akan bertambah sehingga ibu dapat menjadi calon akseptor KB pasca persalinan nanti nya (Dewi, 2011).

Ibu postpartum tidak segera menggunakan kontrasepsi karena masih merasa bingung dengan penentuan alat kontrasepsi yang akan mereka gunakan, sehingga pemberian informasi tentang pilihan metode atau cara kontrasepsi perlu diberikan pada masa ini. Konseling sering diabaikan, padahal penelitian menunjukkan bahwa pemberian konseling pada periode post partum dapat meningkatkan pengetahuan ibu serta mempengaruhi penggunaan alat kontrasepsi pada ibu post partum, seperti didapatkan hasil bahwa kelompok yang mendapatkan konseling seluruhnya menggunakan kontrasepsi efektif seperti pil, injeksi, implan, dan kondom (BKKBN, 2013).

Hasil Penelitian yang dilakukan oleh Rahayu tahun 2015 terdapat pengaruh yang signifikan antara ada pengaruh konseling $\mathrm{KB}$ terhadap tingkat pengetahuan KB dan minat KB. Faktor yang mempengaruhi pemilihan kontrasepsi adalah pengetahuan tentang efektivitas, keamanan, frekuensi, efek samping, serta kemauan untuk melakukan kontrasepsi secara teratur (Yuhedi dan Kurniawati, 2012). 


\section{METODE PENELITIAN}

Penelitian ini merupakan penelitian pre eksperimental dengan rancangan one group pretest-postest dengan tujuan untuk mengetahui pengaruh konseling kontrasepsi hormonal terhadap tingkat pengetahuan akseptor keluarga berencana pasca persalinan. Penelitian ini dilakukan di BPM Lismarini Palembang pada tanggal 19 Mei-8 Juni tahun 2016. Populasi dalam penelitian ini adalah semua ibu nifas yang ada di wilayah kerja BPM Lismarini. Teknik sampling yang digunakan dalam penelitian ini adalah purposive sampling didapatkan sampel sebanyak 17 orang responden.

Teknik pengumpulan data dengan cara wawancara sedangkan instrumen yang digunakan adalah kuisioner (daftar pertanyaan) yang telah dinyatakan valid dan reliabel. Pengolahan data menggunakan analisis univariat dan analisis bivariat dengan uji $\mathrm{T}$ tes dependen, Test of Normality Shapiro-Wilk.

\section{HASIL}

\section{Tingkat Pengetahuan KB Sebelum Diberi Konseling}

Pada Tabel 1 di bawah ini, jumlah responden yaitu 17 orang dapat dilihat bahwa rata-rata skor tingkat pengetahuan sebelum diberikan konseling $\mathrm{KB}$ adalah $(6,12)$ yang didapatkan dari 15 pertanyaan di kuesioner, dengan standar deviasi 1,928. Skor terkecil adalah 3, dan skor terbesar adalah 10. Dari hasil estimasi dapat disimpulkan bahwa 95\% diyakini bahwa rata-rata skor nilai pengetahuan sebelum diberikan konseling $\mathrm{KB}$ adalah 5,10-7,15.

\begin{tabular}{ccccc} 
Tabel 1 & $\begin{array}{l}\text { Distribusi } \\
\text { Pengetahuan } \\
\text { Konseling KB }\end{array}$ & \multicolumn{2}{c}{$\begin{array}{c}\text { Frekuensi } \\
\text { Sebelum }\end{array}$} & $\begin{array}{r}\text { Tingkat } \\
\text { Diberi }\end{array}$ \\
\hline Variabel & Mean & SD & $\begin{array}{c}\text { Min- } \\
\text { Max }\end{array}$ & $\begin{array}{c}95 \% \\
\text { CI }\end{array}$ \\
\hline & & & & \\
\hline Sebelum & 6,12 & 1,928 & $3-10$ & $\begin{array}{c}5,10- \\
7,15\end{array}$ \\
$\begin{array}{c}\text { Konseling } \\
\text { KB }\end{array}$ & & & & \\
\end{tabular}

\section{Tingkat Pengetahuan KB Sesudah Diberi \\ Konseling}

Pada Tabel 2 di bawah ini, dari jumlah responden yaitu 17 orang dapat dilihat bahwa rata-rata skor tingkat pengetahuan sesudah diberikan konseling $\mathrm{KB}$ adalah $(10,50)$ yang didapatkan dari 15 pertanyaan di kuesioner, dengan standar deviasi 2,556. Skor terkecil adalah 5, dan skor terbesar adalah 14. Dari hasil estimasi dapat disimpulkan bahwa 95\% diyakini bahwa rata-rata skor nilai pengetahuan sesudah diberikan konseling KB adalah 9,14 - 11,86.

\begin{tabular}{|c|c|c|c|c|}
\hline Tabel 2 & $\begin{array}{l}\text { Distribus } \\
\text { Pengetah } \\
\text { Konseling }\end{array}$ & & $\begin{array}{l}\text { rekuensi } \\
\text { Sesudah }\end{array}$ & $\begin{array}{r}\text { Tingkat } \\
\text { Diberi }\end{array}$ \\
\hline Variabel & Mean & SD & $\begin{array}{l}\text { Min- } \\
\text { Max }\end{array}$ & $95 \% \mathrm{CI}$ \\
\hline $\begin{array}{c}\text { Sesudah } \\
\text { Konseling } \\
\text { KB }\end{array}$ & 10,50 & $\begin{array}{l}2,5 \\
56\end{array}$ & $5-14$ & $9,14-11,86$ \\
\hline
\end{tabular}

\section{Pengaruh Konseling Kontrasepsi} Hormonal Terhadap Tingkat Pengetahuan Akseptor Keluarga Berencana Pasca Persalinan

Berdasarkan tabel 3 di bawah ini, menunjukan bahwa untuk mendapatkan nilai rata-rata skor pengetahuan sebelum diberikan konseling di dapatkan dari 15 pertanyaan di kuesinoner yang dimana nilai mean ada $(6,12)$ dan untuk mendapatkan nilai rata-rata skor pengetahuan sesudah diberikan konseling di dapatkan dari 15 pertanyaan di kuesinoner yang dimana nilai mean $(10,50)$, perbedaan dari rataa-rata skor pengetahuan sebelum dan sesudah pemberian konseling ada (4.47) dengan standar deviasi (2.19) Dari hasil estimasi dapat disimpulkan bahwa 95\% diyakini bahwa rata-rata skor nilai pengetahuan sebelum dan sesudah diberikan konseling KB adalah (3.34-5.59) untuk hasil uji statistik dengan menggunakan uji $\mathrm{T}$ didapakan nilai $p$ value $=0,005$ kurang dari $\alpha$ $=0,05(\mathrm{p} \leq 0)$ maka dapat disimpulkan bahwa ada pengaruh sebelum dan sesudah di berikan konseling terhadap tingkat pengetahuan akseptor KB.

\begin{tabular}{|c|c|c|c|c|c|c|}
\hline Tabel 3 & & $\begin{array}{l}\text { igaru } \\
\text { rmon } \\
\text { getah }\end{array}$ & $\begin{array}{l}\text { an } \\
\text { Pa }\end{array}$ & $\begin{array}{l}\text { onseling } \\
\text { Terhadap } \\
\text { Akseptor } \\
\text { sca Persali }\end{array}$ & $\begin{array}{r}\text { Kontr } \\
\text { Ti } \\
\text { Kel } \\
\text { inan }\end{array}$ & $\begin{array}{l}\text { sepsi } \\
\text { lgkat } \\
\text { larga }\end{array}$ \\
\hline variabel & $\mathrm{n}$ & Mean & SD & $\begin{array}{l}\text { Perbedaan } \\
\text { Mean } \pm \text { SD }\end{array}$ & $\begin{array}{c}95 \% \\
\text { CI }\end{array}$ & $\begin{array}{c}p \\
\text { Value }\end{array}$ \\
\hline $\begin{array}{l}\text { Sebelum } \\
\text { diberikan } \\
\text { konseling }\end{array}$ & 17 & 6,12 & 1,928 & $4.47 \pm 2.19$ & $\begin{array}{l}3.34- \\
5.59\end{array}$ & 0,005 \\
\hline $\begin{array}{l}\text { Setelah } \\
\text { diberikan } \\
\text { konseling }\end{array}$ & 17 & 10,50 & 2,556 & & & \\
\hline
\end{tabular}




\section{PEMBAHASAN}

\section{A. ANALISIS UNIVARIAT}

Tingkat pengetahuan sebelum diberikan konseling KB berdasarkan hasil Tabel 1 menunjukkan bahwa dari 17 responden yang pengetahuannya kurang dengan nilai rata-rata adalah nilai pengetahuan sebelum diberikan konseling adalah 6,12 dengan standar deviasi 1,928. Nilai minimum adalah 3 dan maksimum adalah 10. Sehingga pada tingkat kepercayaan 95\% rata-rata nilai pengetahuan sebelum diberikan konseling adalah 5,10 - 7,15.

Hasil tersebut sesuai dengan penelitian Rahayu (2015), tentang Pengaruh konseling terhadap tingkat pengetahuan dan minat menjadi akseptor KB di Puskesmas Melati Yogyakarta dengan analisis uji statistik uji T, hasil diketahui bahwa pengetahuan sebelum dilakukan konseling KB yaitu 19 responden (63,3\%) memiliki pengetahuan baik, sebanyak 10 responden $(33,3 \%)$ memiliki pengetahuan cukup dan sebanyak 1 responden $(3,33 \%)$ memiliki pengetahuan kurang.

Sesuai dengan teori Sulistyawati (2012) yang menyatakan Ibu postpartum tidak segera menggunakan kontrasepsi karena masih merasa bingung dengan penentuan alat kontrasepsi yang akan mereka gunakan. Kebingungan dari ibu postpartum mencerminkan kurangnya pengetahuan yang dimilliki oleh ibu postpartum, sehingga konseling perlu diberikan pada masa ini.

Selain itu dari observasi yang dilakukan peneliti pada ibu nifas di wilayah kerja BPM Lismarini palembang di dapatkan fakta bahwa sebagian besar ibu yang sudah melahirkan belum menggunakan kontrasepsi karena masih kurangnya pengetahuan tentang alat kontrasepsi sehingga diperlukan pemberian konseling sehingga ibu dapat menjadi calon akseptor KB pasca persalinan nanti nya.

Tingkat pengetahuan setelah diberikan konseling KB berdasarkan data pada Tabel 2 hasil analisis didapatkan rata-rata nilai pengetahuan sesudah diberikan konseling $\mathrm{KB}$ adalah 10,50 dengan standar deviasi 2,556. Nilai minimum adalah 5 dan maksimum adalah 14 . Sehingga pada tingkat kepercayaan $95 \%$ rata-rata nilai pengetahuan setelah diberikan konseling KB adalah 9,14-11,86. Hal ini menunjukkan bahwa terdapat perbedaan yang nyata terhadap pengetahuan sebelum dan setelah pemberian konseling $\mathrm{KB}$ dengan melihat nilai rata-rata nilai pengetahuannya. Dengan kata lain pemberian konseling KB efektif dalam meningkatkan pengetahuan tentang $\mathrm{KB}$.

Hal ini sesuai dengan penelitian Rahayu (2015), tentang Pengaruh konseling terhadap tingkat pengetahuan dan minat menjadi akseptor KB di puskesmas melati yogyakarta dengan analisis uji statistik uji $\mathrm{T}$, hasil diketahui bahwa Pengetahuan setelah dilakukan konseling KB sebanyak 20 responden $(66,67 \%)$ memiliki pengetahuan baik dan sebanyak 10 responden $(33,33 \%)$ memiliki pengetahuan cukup.

Hal ini sejalan dengan teori Yuhedi dan Kurniawati (2012) yang menyatakan bahwa konseling kontrasepsi adalah bagian dari rangkaian pelayanan Keluarga Berencana (KB) dan Kesehatan Reproduksi (KR), konseling dapat membuat klien merasa puas dan juga akan membuat klien lebih lestari menggunakan kontrasepsi nya dan lebih berhasil, kegiatan yang di lakukan konseling, antara lain menjelaskan berbagai pilihan kontrasepsi, memberikan informasi selengkap mungkin terkait kontrasepsi (arti $\mathrm{KB}$, manfaat $\mathrm{KB}$, metode $\mathrm{KB}$, berbagai isu tentang kontrasepsi dan penjelasannya, pola perencanaan keluarga dan penggunaan kontrasepsi yang rasional, dan rujukan pelayanan kontrasepsi), membantu peserta menentukan pilihannya, dan membantu penyesuaian peserta KB dengan metode yang telah di pakainya.

\section{B. ANALISIS BIVARIAT}

Berdasarkan hasil uji $T$ dan data pengukuran Pengetahuan sebelum dan sesudah pemberian konseling $\mathrm{KB}$, didapatkan nilai signifikansi 0,000 yaitu lebih kecil dari $\alpha=0,05$. Ini berarti ada perubahan nilai pengetahuan yang signifikan setelah pemberian konseling KB. Apabila dikaitkan dengan hasil pengetahuan sebelum dan sesudah pemberian konseling KB, maka dapat disimpulkan bahwa ada perubahan nilai pengetahuan yang signifikan setelah pemberian konseling KB. Kesimpulan tersebut sejalan dengan hipotesis yang telah diajukan sebelumnya bahwa ada pengaruh konseling kontrasepsi hormonal terhadap tingkat pengetahuan akseptor keluarga berencana pasca persalinan di wilayah kerja BPM Lismarini Palembang.

Hal ini sejalan dengan penelitian yang dilakukan Rahayu (2015), tentang Pengaruh konseling terhadap tingkat pengetahuan dan minat menjadi akseptor KB di Puskesmas Melati Yogyakarta dengan analisis uji statistik uji $\mathrm{T}$ Hasil penelitian ini menunjukkan nilai perbedaan rata-rata (mean) antara pre-test dan post-test 
adalah 3,60 dan nilai $p=0,003(p<0,05)$ berarti terdapat pengaruh antara konseling terhadap tingkat pengetahuan ibu nifas.

Hal ini sejalan dengan teori Saifuddin (2010), Seperti yang telah diketahui bahwa konseling merupakan salah satu cara pendekatan dalam menyampaikan pendidikan kesehatan untuk menolong individu. Konseling adalah merupakan bentuk komunikasi interpersonal yang khusus, yaitu suatu pemberian bantuan yang dilakukan kepada orang lain dalam membuat suatu keputusan atau memecahkan suatu masalah melalui pemahaman terhadap klien meliputi fakta-fakta, harapan, kebutuhan dan perasaanperasaan klien. Seringkali konseling diabaikan dan tidak dilaksanakan dengan baik karena petugas tidak mempunyai waktu dan tidak menyadari pentingnya konseling.

Berdasarkan Tabel 3 tentang perubahan pengetahuan sebelum dan sesudah pemberian konseling $\mathrm{KB}$, didapatkan dari 17 responden yang bertambahnya pengetahuan setelah diberikan konseling adalah 16 responden sedangkan yang tidak mengalami perubahan setelah diberikan konseling adalah 1. Dari penjelasan yang telah peneliti uraikan, dapat ditarik kesimpulan bahwa Salah satu upaya untuk meningkatkan pengetahuan akseptor KB melalui konseling KB. konseling KB adalah percakapan yang bertujuan untuk membantu calon peserta $\mathrm{KB}$ agar memahami norma keluarga kecil bahagia sejahtera (NKKBS). Dengan memberikan konseling tentang $\mathrm{KB}$, pengetahuan ibu akan bertambah sehingga ibu dapat menjadi

\section{DAFTAR PUSTAKA}

BKKBN. 2015. Jumlah PUS yang Menggunakan KB Pasca Salin. Jakarta.

BKKBN. 2013. Pasangan Usia Subur. Jakarta

BKKBN Sumsel. 2012. Jumlah Akseptor KB. Sumsel.

BKKBN. 2011. Profil Hasil Pendataan Keluarga Tahun 2011. Jakarta: Badan Kependudukan dan Keluarga Berencana Nasional Direktorat Pelaporan dan Statistik.

BPM Lismarini Palembang. 2015. Jumlah Ibu $K B$. Palembang.

Data Riskesdas. 2013. Metode Pelayanan KB. Jakarta.

Dewi, Vivian Nanny Lia \& Tri Sunarsih. 2011. Asuhan Kebidanan pada Ibu Nifas. Jakarta: Selemba Medika. calon akseptor KB pasca persalinan nantinya dan Faktor yang mempengaruhi pengetahuan antara lain pendidikan, pekerjaan, umur.

\section{SIMPULAN}

Hasil penelitian didapat dari 17 orang responden yang diberikan 15 pertanyaan di kuisioner, maka dapat ditarik kesimpulan sebagai berikut:

1. Rata-rata nilai pengetahuan sebelum diberikan konseling adalah 6,12 dengan standar deviasi 1.928.

2. Rata-rata nilai pengetahuan setelah di berikan konseling adalah 10,50 dengan standar deviasi 2,556 .

3. Ada pengaruh konseling kontrasepsi hormonal terhadap tingkat pengetahuan akseptor keluarga berencana pasca persalinan di wilayah kerja BPM Lismarini Palembang dengan $p$-value $=0,005(p<\alpha)$.

\section{SARAN}

Perlu adanya peningkatan pemberian penyuluhan dan konseling kesehatan oleh tenaga kesehatan kepada ibu pasca persalinan mengenai pemilihan alat kontrasepsi yang tepat dan aman untuk digunakan pada masa nifas dan menyusui.

Profil Dinas Kesehatan Provinsi Sumatera Selatan. 2012. Jumlah Akseptor KB Provinsi SumSel. http://dinkes.sumselprov.go.id/downlot.ph

Rahayu, E. 2015. Pengaruh Konseling Keluarga Berencana Terhadap Tingkat Pengetahuan dan Minat Menjadi Akseptor KB Pasca Persalinan. Jurnal Kesehatan

Saifuddin, A. 2010. Buku Panduan Praktis Pelayanan Kontrasepsi. Jakarta: YBP-S Sugiyono.

Sulistiawati, A. 2012, Pelayanan Keluarga Berencana. Jakarta: Selemba Medika.

WHO. 2013. World Health Population Data Sheet.

Yuhedi, L \& Kurniawati, T. 2012. Buku Ajar Kependudukan dan Pelayanan KB. Jakarta: EGC. 